\title{
Associations of herd-level housing, management, and lameness prevalence with productivity and cow behavior in herds with automated milking systems
}

\author{
M. T. M. King, ${ }^{*}$ E. A. Pajor,† S. J. LeBlanc, $\ddagger$ and T. J. DeVries ${ }^{* 1}$ \\ *Department of Animal Biosciences, University of Guelph, Guelph, Ontario, N1G 2W1, Canada \\ †Faculty of Veterinary Medicine, University of Calgary, Calgary, Alberta, T2N 1N4, Canada \\ ‡Department of Population Medicine, University of Guelph, Guelph, Ontario, N1G 2W1, Canada
}

\section{ABSTRACT}

Lameness is problematic for herds with automated milking systems (AMS) due to negative effects on milking frequency and productivity. The objective of this study was to evaluate how management, barn design, and the prevalence of lameness relate to productivity and behavior at the herd level in AMS. Details about barn design, stocking density, and management were collected from 41 AMS farms in Canada (Ontario: n = 26; Alberta: $\mathrm{n}=15$ ). We collected milking data for all cows on each farm, plus lying behavior data for 30 cows/farm during a 6-d period. Farms averaged $105 \pm$ 56 lactating cows and $2.2 \pm 1.3$ AMS units. Forty cows/ farm were gait scored (or 30\% of cows for herds with $>130$ cows) using a numerical rating system (NRS; 1 $=$ sound to $5=$ extremely lame). Cows were defined as clinically lame with NRS $\geq 3$ (mean $=26.2 \pm 13.0 \%$ / herd) and severely lame with NRS $\geq 4$ (mean $=2.2 \pm$ $3.1 \% /$ herd). The prevalence of both clinical and severe lameness were negatively associated with environmental temperature. Clinical lameness tended to be less prevalent with more frequent scraping of manure alleys. The prevalence of severe lameness was positively associated with stocking density and curb height of the lying stalls. Milking frequency/cow per day was negatively related to the ratio of cows to AMS units. Doubling the prevalence of severe lameness (i.e., from 2.5 to $5 \%$ ) was associated with reductions in milk production of $0.7 \mathrm{~kg} /$ cow per day and $39 \mathrm{~kg} / \mathrm{AMS}$ per day. Milk/AMS was positively associated with more cows/AMS $(+32 \mathrm{~kg} /$ cow). Fewer cows were fetched to the AMS with more frequent alley scraping. Lying behavior was associated with the frequency of feed push-ups, stall base, and environmental temperature. These results highlight the need for AMS producers to identify and reduce clinical lameness because $26 \%$ of cows/herd were clinically

Received April 17, 2016.

Accepted July 20, 2016.

${ }^{1}$ Corresponding author: tdevries@uoguelph.ca lame. Further, the results indicate that more frequently scraped alleys and optimal stocking densities are associated with improved cow mobility, productivity, and voluntary milking behavior.

Key words: automated milking, behavior, lameness, management

\section{INTRODUCTION}

Successful farms with automated milking systems (AMS) are those with high production, good health, and little need to fetch cows for milking. Before managing behavior and productivity at a cow level, barns must be well designed and managed with a thorough understanding of the herd-level factors for success with AMS. Thus far, most herd-level AMS studies have been focused on barn design (various types of cow traffic systems; reviewed by Jacobs and Siegford, 2012) and the manipulation of supplemental feed (provision, amount, composition, and location relative to the AMS; e.g., Prescott et al., 1998; Halachmi et al., 2006; Scott et al., 2015). A recent study by Tremblay et al. (2016) of more than 600 North American AMS herds analyzed associations of barn design and management with production per cow and per AMS. Several significant factors were identified, including cow traffic, the number of AMS per pen, the number of cows per AMS, and whether barns were new or retrofitted (Tremblay et al., 2016). Greater stocking density at the AMS has previously been associated with enhanced milk production per AMS but also with reduced milking frequency per cow (Castro et al., 2012; Deming et al., 2013b). Supporting this, Tremblay et al. (2016) found a negative association between cows per AMS and milk yield per cow at lower milking frequencies $(2.0 \times / \mathrm{d})$, but an inverse association was found at higher milking frequencies $(3.0 \times / \mathrm{d})$. Furthermore, Castro et al. (2012) provided theoretical optimal stocking densities under ideal conditions, and thus, more research is needed under commercial conditions to identify the optimal stocking density at the AMS. Other herd-level housing and management 
factors studied in AMS have been the frequency of feed delivery and feed bunk space available per cow. Milk yield per cow was positively associated with linear bunk space per cow in AMS (Deming et al., 2013b). In conventional parlor-milking farms, Bach et al. (2008) associated production with the number of lying stalls per cow (85\% of farms in that study housed lactating cows in freestalls); no work has yet quantitatively investigated this association in AMS herds.

Management of rest areas and lying behavior are also crucial to productivity and health, especially due to the bidirectional relationship between lameness and lying time: longer standing time and perching are risk factors for lameness, but once lame, cows spend more time lying down (Galindo and Broom, 2000; Deming et al., 2013a). Researchers have recently estimated mean herd-level lameness prevalence in AMS barns in Canada and the United States to be $15 \%$ (Westin et al., 2016b). This was lower than estimates reported in conventional freestall farms in British Columbia (28\%), California (31\%), northeastern United States (55\%; von Keyserlingk et al., 2012), and other parts of Canada (21\%; Solano et al., 2015). Even so, mobility should remain a priority in AMS as lameness has negative effects on the willingness of cows to milk voluntarily (Bach et al., 2007; Borderas et al., 2008). Understanding the herd-level risk factors for lameness is complicated by the multi-factorial nature of this condition. At present, across milking systems, research supports the influence of nutrition, flooring, pasture access, and season, as well as the size, availability, base, and bedding of rest areas on lameness and cow behavior (Bicalho and Oikonomou, 2013; Refaai et al., 2013; Mahendran and Bell, 2015). In AMS specifically, only one study has investigated herd-level risk factors of lameness, which were obstructed lunge space, narrow stalls, and narrow feed alleys, whereas sand-based stalls tended to lower the probability of lameness (Westin et al., 2016b). With regard to lying time at the cow level, researchers found that bunk space per cow and the frequency of feed push-ups were positively associated with daily lying time in AMS (Deming et al., 2013b), but no work has evaluated this at the herd level. Aside from those findings, milking activity, production, and lying behavior have not been analyzed in any study at a herd level and many unidentified associations remain between management, barn design, lameness prevalence, and productivity in AMS.

Therefore, this study evaluated the associations of herd-level factors with the following outcomes: lameness prevalence, lying behavior, milking frequency, and milk production. Factors assessed included feeding, manure, and bedding management, barn design, and stocking density relative to feed bunk space, lying stall availability, and the number of AMS units. Our specific objectives were to (1) assess the effect of herd-level factors on the prevalence of lameness in commercial AMS farms, and (2) examine how lameness and other herdlevel factors influence milking frequency, production, and lying behavior in AMS herds.

\section{MATERIALS AND METHODS}

\section{Farm Selection}

We visited 41 commercial dairy farms with AMS (Ontario: $\mathrm{n}=26$; Alberta: $\mathrm{n}=15$ ) from October 2014 to June 2015. Target sample size was determined through power analysis using the Power Analysis and Sample Size software program (PASS, Kaysville, UT; Hintze, 2008). Estimates of variation for the primary response, dependent variables (including lameness prevalence, lying behavior, milking frequency, and yield) were based on previously reported values from similar herd-level studies (Espejo et al., 2006; Ito et al., 2009; Castro et al., 2012; Sova et al., 2013). An estimated minimum sample size of 40 herds was determined sufficient to detect a $10 \%$ difference in prevalence of the dependent variables, with $95 \%$ confidence.

Using contact lists provided by AMS dealers in Canada and by Alberta Milk (Edmonton, Alberta, Canada), AMS producers were contacted via phone or e-mail and asked to participate in the study. Selection criteria required that farms milk Holstein cows with an AMS exclusively and to have done so for a minimum of 5 mo. The distribution of AMS types was 25 Astronauts (Lely Industries N.V., Maassluis, the Netherlands), 15 VMS (DeLaval International AB, Tumba, Sweden), and one MIone (GEA Farm Technologies GmbH, Siemensstraße, Germany). Eight farms used a form of guided cow traffic for the majority of their herd and 33 farms used free cow traffic designs. All farms had freestall barns except for one bedded-pack barn. The study design was approved by the University of Guelph Animal Care Committee and Research Ethics Board, and animal use complied with the guidelines of the Canadian Council on Animal Care (2009).

\section{Data Collection}

Farms were visited twice, $7 \mathrm{~d}$ apart, to collect 6 complete days (each representing a 24-h period between 0000 and $2359 \mathrm{~h}$ ) of milking and lying behavior data for each farm. At each visit, we recorded the number of lactating cows in total. Herd-level stocking densities were calculated as the average number of lactating cows in the main herd relative to the number of lying stalls available to this group $\times 100 \%$; data for this were not 
available for the one bedded-pack barn. The number of cows per AMS unit was calculated as the average number of lactating cows per farm relative to the available number of AMS units. Cow lists with parity and DIM details were collected from the AMS computer of each farm; these data were used to calculate the average parity and DIM of each herd.

\section{Management and Housing Survey}

Producers were interviewed about routine management practices on the first visit to each farm including information about feed delivery, feed push-ups, bedding, and manure alley management. Type of bedding and the base material of lying stalls were recorded, as were the types of flooring near the feed bunk, lying stalls, and crossover alleys near AMS units. The length of the feed bunk and stall dimensions were measured by the researchers. Based on measurements of 4 randomly selected stalls per farm (or 2 stalls per pen if there were $>2$ pens), we calculated the average lying stall width, length, and curb height, as well as neck rail height, and distance from the neck rail to the back of the stall (methodology adapted from von Keyserlingk et al., 2012).

\section{Assessment of Lameness}

On the first visit to all farms, cows were individually locomotion scored by one observer on a 5 -point numerical rating system (NRS) at increments of 1 (Flower and Weary, 2006). A total of 40 cows were scored per farm, or a minimum of $30 \%$ of herds with $>130$ milking cows, to accurately represent the prevalence of clinical (NRS $\geq 3$ ) and severe lameness (NRS $\geq 4$ ) in each herd (Endres et al., 2014). Locomotion scoring was performed on a random sample of cows from a clear posterior side angle, only while cows took at least 6 strides on flat flooring, making sure they exhibited no other gait aside from walking and were not stumbling, falling, defecating, urinating, or being restricted from free movement by a nearby cow (Flower and Weary, 2006). We used systematic random sampling to select individuals by only including every nth cow, based on the number of cows needed relative to the size of each pen. This ensured that cows were selected proportionately from all parts within a pen (i.e., those lying down, feeding, standing idly, and so on). In cases of farms housing milking cows in more than one pen, a proportionate number of cows per pen were selected to ensure that a representative and random sample was achieved; this included cows separated into smaller treatment/ separation pens. We did not score, or include in our analysis, any cow without voluntary access to an AMS.
Based on these results, we calculated the prevalence of clinically lame cows (\% of cows with NRS $\geq 3$ ) and the prevalence of severely lame cows (\% of cows with NRS $\geq 4$ ) for each farm (Endres et al., 2014).

\section{Milking Activity and Yield}

Milk visits and related production parameters were automatically recorded by the AMS computer system of each farm. Six complete days of data for the whole herd were extracted by research personnel on the second (and final) visit and included information such as date, time, duration, and the outcome of each visit of each cow to the AMS unit (failure, refusal, successful milking). Milk data were completely unavailable for one farm, and at another, could only be extracted manually, which was done for the 30 cows used for lying time evaluation (see below). For both successful and failed milkings, AMS systems recorded total yield for each cow. Respectively, successful and failed milkings were defined as those at which teat cup attachment was successful or not, and whether the amount of milk collected either exceeded or did not meet the system requirement to qualify as a milking event. Data were summarized daily to record the frequency of successful milkings per farm per day and expressed on a per cow basis. Daily milk yield was calculated as the sum of all milk collected per cow per day, whether it was from a successful or failed milking. Daily means were calculated per farm on a per cow basis, and the $6 \mathrm{~d}$ were averaged into one value per farm for each outcome variable. Daily milk harvested per AMS was calculated by dividing daily farm milk production by the number of AMS units, and again averaged across the 6-d period into one value per farm. Producers were also asked to record every cow they fetched for all milkings, which allowed us to calculate the 6 - $\mathrm{d}$ average of the percentage of fetched cows (i.e., any cow fetched at least once in a day) and involuntary milkings (total number of fetched milkings in a day). Fetch cow data were missing or incomplete for 6 farms and, therefore, not used in any analysis. Involuntary/ fetched milkings were defined solely based on whether the producer fetched the cow and were classified independently from the success of the milking.

\section{Lying Behavior}

Electronic data loggers (HOBO Pendant G Logger, Onset Computer Corporation, Pocasset, MA) were used to record lying behavior, as validated by Ledgerwood et al. (2010). Loggers were fitted to a subsample of 30 cows, a sample size previously observed to accurately represent lying behavior of herds of similar size to the current study (Ito et al., 2009). These 30 individuals 
were selected from the sample of cows scored for lameness. After loggers were attached below the hock of the medial side of either hind leg using veterinary bandaging tape, they remained attached for approximately 7 $\mathrm{d}$ to capture a complete 6 -d data collection period and were removed on the second visit. Data were collected at 1-min intervals and were used to calculate daily standing and lying time $(\mathrm{min} / \mathrm{d})$ and the length of each lying bout ( $\mathrm{min} /$ bout). If a producer removed a logger before the end of the 6-d period, only complete days were included in the analysis. Across all farms and cows observed ( $\mathrm{n}=1230$ cows), lying data were completely or partially missing for 16 and 14 cows, respectively. Data for the 30 focal cows per farm were averaged daily, and averaged over $6 \mathrm{~d}$ into value per farm for each lying behavior variable.

\section{Milk Quality and Environmental Temperature}

The DHIA (CanWest DHI, Guelph, Ontario, Canada) data on SCC were available from 26 farms (Ontario: $\mathrm{n}$ = 19; Alberta: $\mathrm{n}=7$ ) and were collected from the test date nearest to the data collection period. No DHIA data were included if the test occurred $>20 \mathrm{~d}$ from the data collection period. One value per farm was calculated as the average of all cows' SCC tested on that date. Average daily temperatures were retrieved from Environment Canada weather stations nearest each farm (as validated by Schüller et al., 2013) for each 6-d collection period and averaged into one value per farm.

\section{Statistical Analyses}

Prior to analyses, all data were screened for normality by assessing the distribution of data and any outliers using the UNIVARIATE procedure of SAS (version 9.4, SAS Institute Inc., Cary, NC). Data for the prevalence of severe lameness (NRS $\geq 4$ ), fetched cows, and involuntary milkings, were right-skewed; therefore, these were transformed by taking the natural logarithm of the value +1 . Data for SCC were also right-skewed and natural log-transformed. Continuous predictor variables included average parity, DIM, stocking density (\% cows/lying stalls), cows per AMS, frequencies of feed push-ups and alley scraping, lying stall dimensions, linear feed bunk space per cow, and environmental temperature (Table 1). The remaining variables were categorized before analysis: stall base, flooring type near feed bunks, and the frequency at which producers raked stalls per day, delivered feed per day, and fetched cows per day. Univariable models were then used to screen the various independent variables (as fixed effects) in linear regression models using the MIXED procedure of SAS. Degrees of freedom for fixed effects were estimated using the Kenward-Roger option in the MODEL statement. Outcome variables averaged at a herd level and expressed on a per cow basis were SCC, daily milk yield, milking frequency, lying time, and lying bout length; those expressed on a per farm basis were the prevalence of clinical and severe lameness, milk harvested per AMS, and the proportion of fetched cows and involuntary milkings (Table 2).

Given that data collection in the 2 provinces occurred at different times of year, location (Alberta or Ontario) was tested as a fixed effect in all univariable models, as was temperature (continuous), on various outcome variables in SAS (SAS Institute Inc.). In all models, the random effect was herd. Only variables with $P<0.25$ in the univariable models were included in multivariable models (Dohoo et al., 2009). In cases where temperature and location were both retained for model building, we chose the variable with the lower $P$-value to include in the multivariable model. Multivariable (mixed effect) linear regression models were then used to associate the effects of predictor variables on outcome variables using the MIXED procedure of SAS. When analyzing Pearson correlation coefficients between independent variables (CORR procedure of SAS), if any variables were correlated $(r>0.6)$, the most biologically plausible variable was retained for the multivariable model. Manual backward elimination was then used to remove any variables with $P>0.1$; those retained were considered significant at $P \leq 0.05$ and tendencies at $P \leq 0.1$.

\section{RESULTS AND DISCUSSION}

\section{Housing, Environment, and Management}

Information on herd demographics, housing, and management is provided in Table 1. Mean herd DIM and parity were $176 \mathrm{~d}$ and 2.2 lactations, respectively. These values are comparable to recent surveys of AMS herds (Deming et al., 2013b) and conventional freestall herds (Charlton et al., 2014) in Canada. The average herd size of study farms was 105 lactating cows, with 2.2 AMS units. Therefore, the average number of cows per AMS unit was 49, similar to the 51 cows/AMS reported by Tremblay et al. (2016), which is well below the industry expectation of 60 cows per AMS unit (Jacobs and Siegford, 2012; Deming et al., 2013b) and slightly less than other reports of 54 and 55 cows/AMS (Deming et al., 2013b; Westin et al., 2016b).

Stocking density in lying stalls was also low (mean $=$ $89 \%$; Table 1); this was below the $93 \%$ found by Westin et al. (2016b) in AMS herds, the recommendation $(\leq 100 \%)$ and requirement $(\leq 120 \%)$ of the Canadian Code of Practice for Dairy Cattle (DFC-NFACC, 2009), 
Table 1. Descriptive statistics of herd information, housing, and management of 41 Canadian herds with automated milking systems

\begin{tabular}{|c|c|c|c|c|}
\hline Variable & Mean & $\mathrm{SD}$ & Minimum & Maximum \\
\hline Months since AMS installation & 44.2 & 40.8 & 5 & 168 \\
\hline DIM $^{1}$ & 175.6 & 22.4 & 126.7 & 236.8 \\
\hline Parity $^{1}$ & 2.2 & 0.3 & 1.5 & 3.1 \\
\hline Farm size $^{2}$ (no. of lactating cows) & 105 & 56 & 37 & 365 \\
\hline Cows per $\mathrm{AMS}^{2}$ & 49.4 & 7.9 & 34.5 & 63.0 \\
\hline Number of AMS units total ${ }^{2}$ & 2.2 & 1.3 & 1 & 9 \\
\hline Stocking density ${ }^{2}($ cows/lying stalls $\times 100 \%)$ & 88.6 & 17.2 & 58.8 & 115.7 \\
\hline Feed bunk space $3(\mathrm{~cm} / \mathrm{cow})$ & 67.1 & 17.4 & 31.6 & 95.1 \\
\hline Linear water $\operatorname{access}^{3}(\mathrm{~cm} / \mathrm{cow})$ & 9.4 & 3.3 & 4.1 & 17.0 \\
\hline Frequency of alley cleaning ${ }^{4}$ (no./d) & 8.8 & 5.1 & 0.5 & 24 \\
\hline Frequency of feed push-ups ${ }^{4}$ (no./d) & 8.0 & 6.1 & 2 & 24 \\
\hline \multicolumn{5}{|l|}{ Stall dimensions } \\
\hline Curb height $^{3}(\mathrm{~cm})$ & 20.9 & 3.4 & 16.3 & 28.8 \\
\hline $\mathrm{Width}^{3}(\mathrm{~cm})$ & 115.6 & 3.3 & 107.8 & 128.5 \\
\hline Length $^{3}(\mathrm{~cm})$ & 249.4 & 18.9 & 214.8 & 283.5 \\
\hline Neck rail distance from rear curb $^{3}(\mathrm{~cm})$ & 166.9 & 11.2 & 137.8 & 183.8 \\
\hline Neck rail height ${ }^{3}(\mathrm{~cm})$ & 122.5 & 6.8 & 106.3 & 136.5 \\
\hline Daily environmental temperature ${ }^{5}\left({ }^{\circ} \mathrm{C}\right)$ & 4.4 & 11.4 & -15.3 & 19.3 \\
\hline Ontario herds (October 2014-February 2015) & -1.6 & 9.9 & -15.3 & 12.0 \\
\hline Alberta herds (May-June 2015) & 14.9 & 3.1 & 12.4 & 19.3 \\
\hline
\end{tabular}

${ }^{1}$ Herd DIM and parity information was extracted on the final visit.

${ }^{2}$ Average number of total lactating cows, cows per automated milking system (AMS), and stocking density in lying stalls.

${ }^{3}$ Dimensions were measured by research personnel on the final visit.

${ }^{4}$ Management practices described by producers.

${ }^{5}$ Average temperature during 6-d data collection periods at Environment Canada weather stations nearest each farm.

as well as averages from North American freestall herds (von Keyserlingk et al., 2012). Resting surfaces were either some form of mattress $(\mathrm{n}=30)$ or deep bedding $(\mathrm{n}=11)$ and were raked $\leq 2 \times / \mathrm{d}(\mathrm{n}=29)$ or $>2 \times / \mathrm{d}(\mathrm{n}$ $=12$ ). Curb height at the back of lying stalls averaged $21 \mathrm{~cm}$, similar to the $20 \mathrm{~cm}$ reported by Westin et al. (2016b). Mean stall dimensions (Table 1) fell within, but in the lower range of, recommended stall size guidelines (Cook, 2009), aside from stall length, which was longer than recommended. Mean stall width (116 $\mathrm{cm})$ fell within reported averages from North American freestall herds (112 to $120 \mathrm{~cm}$; von Keyserlingk et al., 2012; Westin et al., 2016b). Stalls were longer than in other freestall herds (249 vs. 231 to $243 \mathrm{~cm}$ ) and neck rails were higher (123 vs. 112 to $118 \mathrm{~cm}$ ), but the placement of neck rails from the rear curb was similar to previous reports (167 vs. 160 to 175 cm; von Keyserlingk et al., 2012; Westin et al., 2016b).

Even though 11 farms provided $<60 \mathrm{~cm}$ of bunk space/cow, 4 of which were $<40 \mathrm{~cm} /$ cow, bunk space

Table 2. Descriptive statistics of herd-level lameness prevalence, milking activity, and lying behavior variables for 41 Canadian herds with automatic milking systems

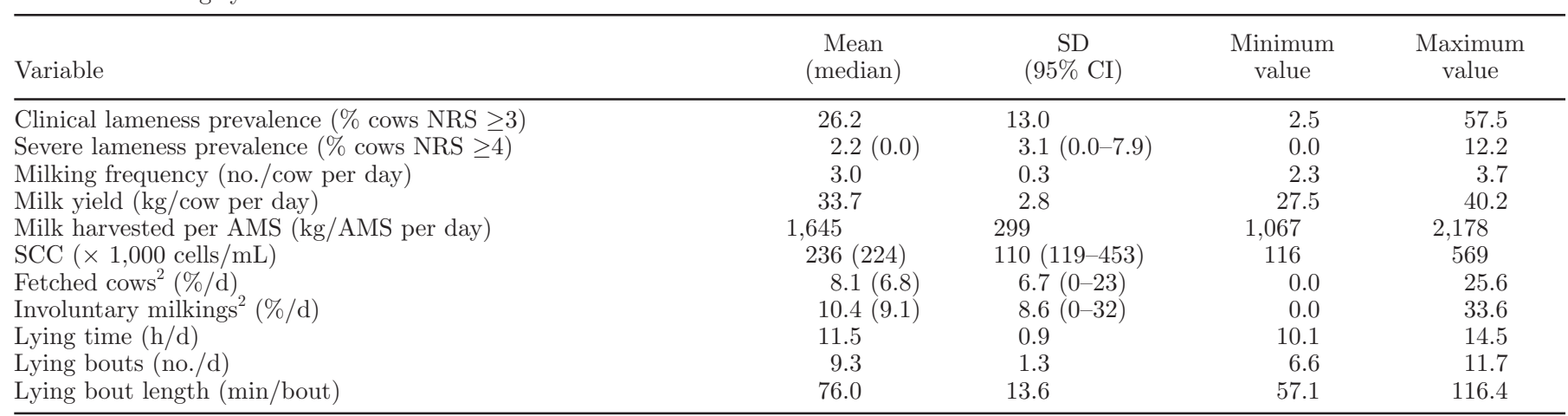

${ }^{1} \mathrm{NRS}=$ numerical rating system; AMS = automated milking system. Median values and 95\% CI are presented for those variables that were not normally distributed.

${ }^{2}$ Daily percentages of fetched cows and involuntary milkings relative to herd size. 
still averaged $67 \mathrm{~cm} / \mathrm{cow}$ (Table 1). Thus, herds generally exceeded the recommendation for linear feed bunk space in the Canadian Code of Practice for Dairy Cattle (60 cm/cow; DFC-NFACC, 2009), similar to herds in Westin et al. (2016b). All farms fed a supplemental concentrate in the AMS; 38 farms fed a partial mixed ration in the bunk and 3 fed separate components. Fresh feed was delivered to bunks $\leq 1 \times / \mathrm{d}(\mathrm{n}=23)$ or $>1 \times / d(n=18)$ and feed push-ups took place $8 \times / d$, on average, ranging from 2 to $24 \times /$ d. Seven farms had closed mangers and did not push up feed; thus, data from these farms were excluded when using push-up frequency as a predictor variable. Feed push-ups were more frequent in this study compared with the 1.6 push-ups/d reported for Ontario AMS farms (Deming et al., 2013b) and 4.6 push-ups/d reported for conventional freestall parlor-milking farms in Ontario (Sova et al., 2013).

Flooring near the feed bunk was made of rubber (n $=11)$ or concrete $(\mathrm{n}=30)$. The frequency of alley scraping ranged from once every $2 \mathrm{~d}$ to continuously $24 \times / \mathrm{d}$ (Table 1$)$. Cows were fetched $2 \times / \mathrm{d}(\mathrm{n}=26)$ or $>2 \times / d(n=11)$; data were incomplete for 4 farms. Mean environmental temperatures during data collection on farms in Ontario were $-1.6 \pm 9.9^{\circ} \mathrm{C}$, ranging from -15.3 to $12.0^{\circ} \mathrm{C}$, compared with $14.9 \pm 3.1^{\circ} \mathrm{C}$ in Alberta, ranging from 12.4 to $19.3^{\circ} \mathrm{C}$ (Table 1).

\section{Lameness Prevalence}

Across farms the mean herd-level prevalence of clinical lameness (NRS $\geq 3$ ) was $26 \%$ and the mean herdlevel prevalence of severe lameness (NRS $\geq 4$ ) was $2.2 \%$ (Table 2). Clinical lameness was more prevalent than a recently published estimate of herd-level lameness in North American AMS herds (15\%; Westin et al., 2016b) and more comparable to herd-level prevalence reported in conventional freestall herds in North America (21 to 55\%; von Keyserlingk et al., 2012; Solano et al., 2015). In the current study, a small portion of cows were severely lame, similar to samples of other herds previously studied (4 to 8\%; von Keyserlingk et al., 2012; Westin et al., 2016b). Perhaps there were so few severely lame cows in this study because individual milking in AMS can help producers identify these cows more easily; AMS facilities may also make it easier to separate these cows into smaller groups for treatment with closer access to the AMS. Additionally, producers tend to identify only severely lame cows as being lame (Horseman et al., 2014) and make a large effort to treat these individuals, but may not diagnose cases of lameness until they are well established (on average $65 \mathrm{~d}$ after an external researcher, as found by Leach et al., 2012).
The prevalence of clinical and severe lameness were moderately correlated with one another $(\mathrm{r}=0.5, P<$ 0.001 ), and both were negatively associated with environmental temperature (Table 3). Each $10^{\circ} \mathrm{C}$ increase in temperature was associated with a reduction of 6.3 percentage points (p.p.) in clinical lameness, whereas an increase of $10^{\circ} \mathrm{C}$ from the mean $\left(4.4^{\circ} \mathrm{C}\right)$ was associated with a reduction of 0.6 p.p. in severe lameness prevalence. Lameness and associated hoof lesions are often reported to be more prevalent in winter than summer (Murray et al., 1996; Cook, 2003; Espejo et al., 2006). Producers are more likely to have issues with alley scrapers and footbaths functioning in cold weather, allowing buildup of slurry and reducing the efficacy of footbaths (Cook, 2003). Standing in wet, slippery conditions promotes slips and falls, softening of claws, and transmission of anaerobic bacteria (Borderas et al., 2004; Refaai et al., 2013). Therefore, it may be that winter conditions are the driver of the higher prevalence at lower temperatures. In contrast, high temperatures negatively affect feeding behavior and intake (Chen et al., 2013; Gorniak et al., 2014). This has been hypothesized to predispose cows to acidosis, which has further been suggested to be linked to laminitis (reviewed by Bicalho and Oikonomou, 2013). However, it takes several weeks or months for a visible lesion to be seen following the inciting factor and there also appears to be a lag between lesion development and lameness manifestation within an individual lactation (Mahendran and Bell, 2015). For example, most claw horn lesions develop during early lactation (Mahendran and Bell, 2015), but impaired mobility generally presents in mid-late lactation (Green et al., 2002; Bach et al., 2007; Lim et al., 2015). Therefore, high lameness prevalence in winter may also represent a carryover effect from seasonal management or heat stress (Murray et al., 1996); Sanders et al. (2009) observed the highest incidence rates for hoof lesions in summer, followed by fall. Thus, higher incidence of hoof lesions in summer and fall may explain the greater lameness prevalence in winter months observed in this and other studies.

There tended to be fewer clinically lame cows in herds that scraped manure alleys more frequently (i.e., every 2 extra passes/d were associated with a 1.2 p.p. decrease in clinical lameness; Table 3). There is some empirical support for this finding. The use of automatic alley scrapers can reduce the odds and prevalence of digital dermatitis, interdigital dermatitis, and heel erosion by providing dry, clean flooring (Somers et al., 2003, 2005), whereas wet, slurry-covered flooring may inhibit locomotion (Phillips and Morris, 2000). Lower scraping frequency has been associated with poor hygiene of the lower legs (DeVries et al., 2012); although no measures of hoof health were taken in the DeVries 
et al. (2012) study, cow hygiene has previously been linked with the probability of lameness (Dembelle et al., 2006). Alternatively, other researchers have found that automatic alley scrapers and increased scraping frequency were risk factors for lameness, ulcers, and digital dermatitis, potentially due to physical trauma as cows trip over passing scrapers or the associated wave of slurry soiling their feet (Barker et al., 2007; Cramer et al., 2009; Barker et al., 2010). More work is needed to establish the optimal frequency and timing of alley scraping for freestall herds, especially for AMS herds where cows may be continuously exposed to passing scrapers and waves of slurry, as opposed to conventional herds that may only scrape alleys while cows are moved out of their pens during milking time.

The prevalence of severe lameness was positively associated with increasing stocking density and curb height. A 10 p.p. increase in stocking density above the mean $(88.6 \%)$ was associated with a 0.5 p.p. increase in severe lameness (Table 3 ). This could have been related to reduced daily lying time at higher stocking densities (Fregonesi et al., 2007), which would have increased the risk of lameness by increasing standing and perching time (Leonard et al., 1996; Galindo and Broom, 2000). However, unlike previous studies that reported reductions in lying time at greater stocking densities (Fregonesi et al., 2007), the current study found no association between stocking density and lying behavior parameters (Table 4). A 5-cm increase in curb height above the average $(20.9 \mathrm{~cm})$ was associated with a 1.0 p.p. increase in severe lameness (Table 3). The average curb height in this study was above the recommendation of Cook (2009) and in a past survey of 37 farms, those with curbs higher than $20 \mathrm{~cm}$ were associated with worsened lameness and locomotion rankings (Faull et al., 1996). Higher curbs could protrude above the level of the bedding and reduce available resting space, forcing cows to lay diagonally with a hind leg extending across the curb. With the weight of the leg and potential abrasion from the rough curb surface on the hock, medial ulcers could form (Nordlund and Cook, 2003). Thus, it could be that farms with higher curbs were not providing adequate bedding to reach the top of the curb; unfortunately bedding depth and leg injuries were not measured in this study.

\section{Milking Activity and Production}

Mean herd milking frequency was $3.0 \times / \mathrm{cow} / \mathrm{d}$, with a mean daily yield of $33.7 \mathrm{~kg} /$ cow per day (Table 2 ). Milk harvested per AMS averaged 1,645 kg/d (Table 2 ). Mean milking frequency (expressed per cow per day) was negatively associated with stocking density at the AMS (Table 5). As with other studies, a greater number of cows per AMS negatively affected milking frequency (Castro et al., 2012; Deming et al., 2013b); in the current study, each additional 10 cows/AMS reduced individual milking frequency by $0.22 \times / \mathrm{cow}$ per day (Table 5). Unlike the interaction between milking frequency, stocking density at the AMS, and milk production per cow found by Tremblay et al. (2016), the current study did not find an association between cows per AMS and milk yield per cow. Milk harvested per AMS, however, was positively associated with the number of cows per AMS; each additional cow/AMS was associated with an increase of $32.3 \mathrm{~kg}$ of total milk/ AMS per day (Table 5). This was expected because no herd in the current study milked more than 63 cows/ AMS and each additional cow provided their daily production as additional yield. The common recommendation is to stock groups at approximately 60 cows/AMS (Jacobs and Siegford, 2012). Unfortunately, to date, no research is available in which the upper limit of AMS stocking density has been tested, likely because of cow-

Table 3. Final general linear models of the factors associated with the herd-level prevalence of clinical (locomotion score $\geq 3$ out of 5 ) and severe (locomotion score $\geq 4$ out of 5 ) lameness $(\mathrm{n}=41$ herds)

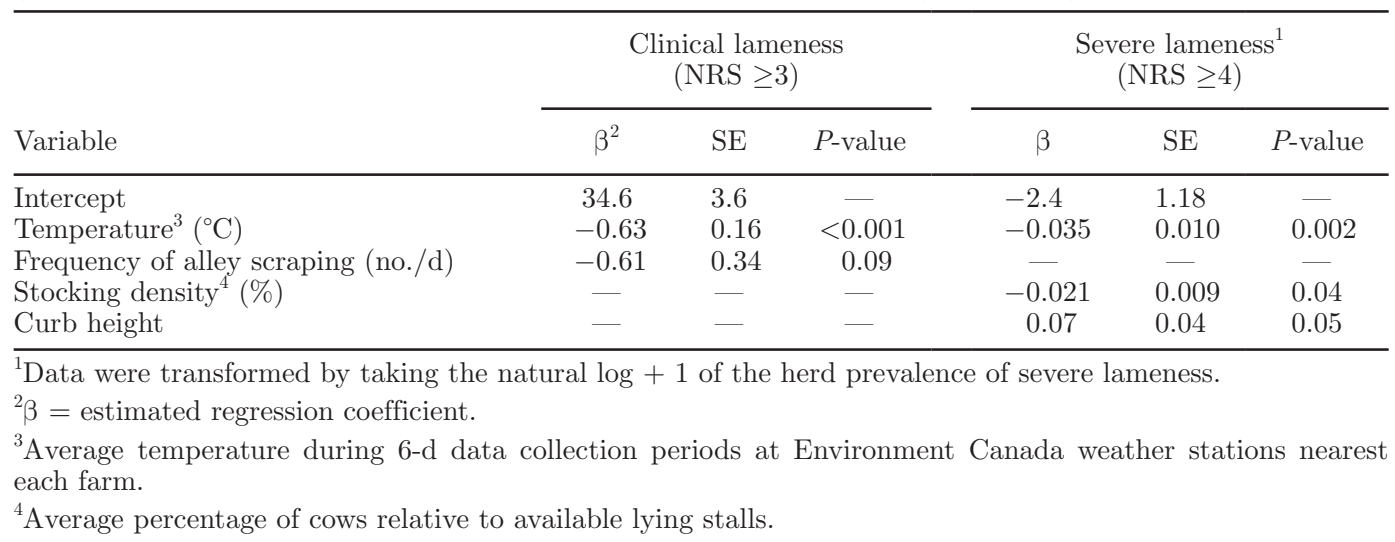


Table 4. Final general linear models of associations of herd average lying behavior variables with explanatory variables

\begin{tabular}{|c|c|c|c|c|c|c|}
\hline \multirow[b]{2}{*}{ Variable } & \multicolumn{3}{|c|}{$\begin{array}{l}\text { Lying time }^{1} \\
(\mathrm{~min} / \mathrm{d})\end{array}$} & \multicolumn{3}{|c|}{$\begin{array}{l}\text { Length of lying } \\
\text { bouts }^{2} \text { (min/bout) }\end{array}$} \\
\hline & $\beta^{3}$ & SE & $P$-value & $\beta$ & $\mathrm{SE}$ & $P$-value \\
\hline Intercept & 675.3 & 15.7 & - & 75.1 & 2.24 & - \\
\hline Temperature ${ }^{4}\left({ }^{\circ} \mathrm{C}\right)$ & -1.46 & 0.79 & 0.07 & -0.47 & 0.16 & 0.005 \\
\hline Frequency of feed push-ups/d & 2.51 & 1.51 & 0.1 & - & - & - \\
\hline Stall base & & & & & & 0.007 \\
\hline Deep bedding & - & - & - & 11.5 & 4.03 & \\
\hline Mattress & - & - & - & Referent & - & \\
\hline
\end{tabular}

specific demands on the AMS that vary based on factors such as milk production, DIM, and parity. Further, management philosophies differ; some producers aim for greater milking frequencies whereas others prioritize total daily yield per cow to maximize efficiency and production per AMS. By modeling data from Galician dairy farms, Castro et al. (2012) suggested that it is possible to maximize milk yield per AMS by stocking at higher rates and reducing individual cow milking frequency up to, for example, approximately 69 cows/ AMS at 2.5 to $2.7 \times / \mathrm{cow} / \mathrm{d}$. Because modeling studies use values specific to those herds, no blanket recommendations can be currently be made about the optimal number of cows per AMS, and this will also depend on milking efficiency of unique herds and producers' management preferences.

Milk production, expressed per cow and per AMS, was negatively associated with severe lameness prevalence. Doubling the prevalence of severe lameness (i.e., from 2.5 to $5 \%$ ) was associated with reductions of $0.7 \mathrm{~kg} / \mathrm{cow}$ per day and $39 \mathrm{~kg} / \mathrm{AMS}$ per day (Table 5). In previous studies of the associations between mobility and milking activity, cows with higher locomotion scores, using similar 5-point scales, produced less milk in fewer total milkings and fewer voluntary milkings (Bach et al., 2007; Deming et al., 2013a). To our knowledge, the current study is the first to report negative effects of lameness on milk production in AMS at the herd level. Median herd SCC was 223,910 cells $/ \mathrm{mL}$ at the nearest DHIA test date (Table 2), which was positively associated with environmental temperature and average DIM of the herd. An increase of 10 DIM above the mean (175.6 DIM) was associated with an increase of 26,660 cells $/ \mathrm{mL}(P=0.02)$. Furthermore, an increase of $10^{\circ} \mathrm{C}$ from the mean $\left(4.4^{\circ} \mathrm{C}\right)$ tended to be associated with an increase of 34,500 cells $/ \mathrm{mL}(P=0.09)$.

Relative to herd size, the proportion of cows fetched for milking and the proportion of total involuntary milkings per day ranged from 0 to $10 \%$ (Table 2). Percentages of cows fetched and of involuntary milkings relative to herd size were both negatively associated with the frequency of alley scraping and tended to be positively associated with stocking density of lying stalls (Table 6). The magnitude of these associations was small. In a herd of 120 cows, for example, running alley scrapers an extra $4 \times / d$ above the mean was associated with fetching 2 fewer cows/d and, therefore, 2 fewer involuntary milkings/d. Although lameness prevalence

Table 5. Final general linear models of the associations of herd average milking activity with herd-level explanatory variables ${ }^{1}$

\begin{tabular}{|c|c|c|c|c|c|c|c|c|c|}
\hline \multirow[b]{2}{*}{ Variable } & \multicolumn{3}{|c|}{$\begin{array}{l}\text { Milking frequency } \\
\text { (no./cow per day) }\end{array}$} & \multicolumn{3}{|c|}{$\begin{array}{c}\text { Milk yield } \\
(\mathrm{kg} / \text { cow per day })\end{array}$} & \multicolumn{3}{|c|}{$\begin{array}{l}\text { Milk harvested per AMS } \\
\text { (kg/AMS per day) }\end{array}$} \\
\hline & $\beta^{2}$ & $\mathrm{SE}$ & $P$-value & $\beta$ & $\mathrm{SE}$ & $P$ & $\beta$ & $\mathrm{SE}$ & $P$-value \\
\hline
\end{tabular}

${ }^{1}$ Data were averaged over 6-d data collection periods.

${ }^{2} \beta=$ estimated regression coefficient.

${ }^{3}$ Data were transformed by taking the natural $\log +1$ of the herd prevalence of severe lameness. NRS $=$ numerical rating system.

${ }^{4}$ Average number of cows per automated milking system (AMS) unit. 


\section{ACKNOWLEDGMENTS}

Special thanks to the participating producers for the use of their animals, facilities, and AMS data. We thank Ivelisse Robles, Patrick Sudds, and Kaitlyn Dancy (University of Guelph, Guelph, ON, Canada), Amanda Bartier, and Christina Tse (University of Calgary, Calgary, $\mathrm{AB}$, Canada) for their technical assistance with data collection. This project was financially supported by a contribution from the Dairy Research Cluster II Initiative, funded by the Dairy Farmers of Canada (Ottawa, ON, Canada), Agriculture and Agri-Food Canada (Ottawa, ON, Canada), the Canadian Dairy Network (Guelph, ON, Canada), and the Canadian Dairy Commission (Ottawa, ON, Canada).

\section{REFERENCES}

Bach, A., M. Dinarés, M. Devant, and X. Carré. 2007. Associations between lameness and production, feeding and milking attendance of Holstein cows milked with an automatic milking system. J. Dairy Res. 74:40-46. http://dx.doi.org/10.1017/S0022029906002184.

Bach, A., N. Valls, A. Solans, and T. Torrent. 2008. Associations between nondietary factors and dairy herd performance. J. Dairy Sci. 91:3259-3267. http://dx.doi.org/10.3168/jds.2008-1030.

Barker, Z. E., J. R. Amory, J. L. Wright, R. W. Blowey, and L. E. Green. 2007. Management factors associated with impaired locomotion in dairy cows in England and Wales. J. Dairy Sci. 90:32703277. http://dx.doi.org/10.3168/jds.2006-176

Barker, Z. E., K. A. Leach, H. R. Whay, N. J. Bell, and D. C. J. Main 2010. Assessment of lameness prevalence and associated risk factors in dairy herds in England and Wales. J. Dairy Sci. 93:932-941. http://dx.doi.org/10.3168/jds.2009-2309.

Bicalho, R. C., and G. Oikonomou. 2013. Control and prevention of lameness associated with claw lesions in dairy cows. Livest. Sci. 156:96-105. http://dx.doi.org/10.1016/j.livsci.2013.06.007.

Borderas, T. F., A. Fournier, J. Rushen, and A. M. B. de Passillé 2008. Effect of lameness on dairy cows' visits to automatic milking systems. Can. J. Anim. Sci. 88:1-8. http://dx.doi.org/10.4141/ CJAS07014.

Borderas, T. F., B. Pawluczuk, A. M. de Passillé, and J. Rushen. 2004. Claw hardness of dairy cows: Relationship to water content and claw lesions. J. Dairy Sci. 87:2085-2093. http://dx.doi. org/10.3168/jds.S0022-0302(04)70026-0.

Castro, A., J. M. Pereira, C. Amiama, and J. Bueno. 2012. Estimating efficiency in automatic milking systems. J. Dairy Sci. 95:929-936. http://dx.doi.org/10.3168/jds.2010-3912.

Canadian Council on Animal Care. 2009. Guidelines on: The care and use of farm animals in research, teaching and testing. Canadian Council on Animal Care, Ottawa, ON, Canada.

Charlton, G. L., D. B. Haley, J. Rushen, and A. M. de Passillé. 2014. Stocking density, milking duration, and lying times of lactating cows on Canadian freestall dairy farms. J. Dairy Sci. 97:26942700. http://dx.doi.org/10.3168/jds.2013-6923.

Chen, J. M., K. E. Schütz, and C. B. Tucker. 2013. Dairy cows use and prefer feed bunks fitted with sprinklers. J. Dairy Sci. 96:50355045. http://dx.doi.org/10.3168/jds.2012-6282.

Cook, N. B. 2003. Prevalence of lameness among dairy cattle in stall surface. J. Am. Vet. Med. Assoc. 223:1324-1328. http://dx.doi. org/10.2460/javma.2003.223.1324.

Cook, N. B. 2009. Free-stall comfort design for maximum cow comfort. Western Canadian Dairy Seminar. Adv. Dairy Technol. 21:255268.

Cook, N. B., T. B. Bennett, and K. V. Nordlund. 2004. Effect of free stall surface on daily activity patterns in dairy cows with relevance to lameness prevalence. J. Dairy Sci. 87:2912-2922. http://dx.doi. org/10.3168/jds.S0022-0302(04)73422-0.

Cramer, G., K. D. Lissemore, C. L. Guard, K. E. Leslie, and D. F. Kelton. 2009. Herd-level risk factors for seven different foot lesions in Ontario Holstein cattle housed in tie stalls or free stalls. J. Dairy Sci. 92:1404-1411. http://dx.doi.org/10.3168/jds.2008-1134.

Dembelle, I., M. Spinka, I. Stehulova, J. Panama, and P. Firla. 2006. Factors contributing to the incidence and prevalence of lameness on Czech dairy farms. Czech J. Anim. Sci. 51:102-109.

Deming, J. A., R. Bergeron, K. E. Leslie, and T. J. DeVries. 2013a. Associations of cow-level factors, frequency of feed delivery, and standing and lying behaviour of dairy cows milked in an automatic system. Can. J. Anim. Sci. 93:427-433. http://dx.doi.org/10.4141/ CJAS2013-055.

Deming, J. A., R. Bergeron, K. E. Leslie, and T. J. DeVries. 2013b. Associations of housing, management, milking activity, and standing and lying behavior of dairy cows milked in automatic systems. J. Dairy Sci. 96:344-351. http://dx.doi.org/10.3168/jds.2012-5985.

DeVries, T. J., M. G. Aarnoudse, H. W. Barkema, K. E. Leslie, and M. A. G. von Keyserlingk. 2012. Associations of dairy cow behavior, barn hygiene, cow hygiene, and risk of elevated somatic cell count. J. Dairy Sci. 95:5730-5739. http://dx.doi.org/10.3168/ jds.2012-5375.

DFC-NFACC (Dairy Farmers of Canada and the National Farm Animal Care Council). 2009. Code of Practices for the Care and Handling of Dairy Cattle. Dairy Farmers of Canada, Ottawa, Ontario, Canada.

Dohoo, I., W. Martin, and H. Stryhn. 2009. Veterinary Epidemiologic Research. VER Inc., Charlottetown, Prince Edward Island, Canada.

Endres, M. I., K. M. Lobeck-Luchterhand, L. A. Espejo, and C. B. Tucker. 2014. Evaluation of the sample needed to accurately estimate outcome-based measurements of dairy welfare on farm. J. Dairy Sci. 97:3523-3530. http://dx.doi.org/10.3168/jds.2013-7464.

Espejo, L. A., M. I. Endres, and J. A. Salfer. 2006. Prevalence of lameness in high-producing Holstein cows housed in freestall barns in Minnesota. 89:3052-3058. http://dx.doi.org/10.3168/jds.S00220302(06)72579-6.

Faull, W. B., J. W. Hughes, M. J. Clarkson, D. Y. Downham, F. J. Manson, J. B. Merritt, R. D. Murray, W. B. Russell, J. E. Sutherst, and W. R. Ward. 1996. Epidemiology of lameness in dairy cattle: The influence of cubicles and indoor and outdoor walking surfaces. Vet. Rec. 139:130-136. http://dx.doi.org/10.1136/vr.139.6.130.

Flower, F. C., and D. M. Weary. 2006. Effect of hoof pathologies on subjective assessments of dairy cow gait. J. Dairy Sci. 89:139-146. http://dx.doi.org/10.3168/jds.S0022-0302(06)72077-X.

Fregonesi, J. A., C. B. Tucker, and D. M. Weary. 2007. Overstocking reduces lying time in dairy cows. J. Dairy Sci. 90:3349-3354. http://dx.doi.org/10.3168/jds.2006-794.

Galindo, F., and D. M. Broom. 2000. The relationships between social behaviour of dairy cows and the occurrence of lameness in three herds. Res. Vet. Sci. 69:75-79. http://dx.doi.org/10.1053/ rvsc.2000.0391.

Gorniak, T., U. Meyer, K. Südekum, S. Dänicke, T. Gorniak, U. Meyer, K. Südekum, and S. Dänicke. 2014. Impact of mild heat stress on dry matter intake, milk yield and milk composition in mid-lactation Holstein dairy cows in a temperate climate. Arch. Anim. Nutr. 68:358-369. http://dx.doi.org/10.1080/174503 9X.2014.950451.

Green, L. E., V. J. Hedges, Y. H. Schukken, R. W. Blowey, and A. J. Packington. 2002. The impact of clinical lameness on the milk yield of dairy cows. J. Dairy Sci. 85:2250-2256. http://dx.doi. org/10.3168/jds.S0022-0302(02)74304-X.

Halachmi, I., E. Shoshani, R. Solomon, E. Maltz, and J. Miron. 2006. Feeding of pellets rich in digestible neutral detergent fiber to lactating cows in an automatic milking system. J. Dairy Sci. 89:32413249. http://dx.doi.org/10.3168/jds.S0022-0302(06)72599-1.

Hintze, J. 2008. PASS 2008. NCSS LLC, Kaysville, UT. www.ncss. com.

Horseman, S. V., E. J. Roe, J. N. Huxley, N. J. Bell, C. S. Mason, and H. R. Whay. 2014. The use of in-depth interviews to un- 
derstand the process of treating lame dairy cows from the farmers' perspective. Anim. Welf. 23:157-165. http://dx.doi. org/10.7120/09627286.23.2.157.

Ito, K., D. M. Weary, and M. A. G. von Keyserlingk. 2009. Lying behavior: Assessing within- and between-herd variation in freestallhoused dairy cows. J. Dairy Sci. 92:4412-4420. http://dx.doi. org/10.3168/jds.2009-2235.

Jacobs, J. A., and J. M. Siegford. 2012. Invited review: The impact of automatic milking systems on dairy cow management, behavior, health, and welfare. J. Dairy Sci. 95:2227-2247. http://dx.doi. org/10.3168/jds.2011-4943.

Leach, K. A., D. A. Tisdall, N. J. Bell, D. C. J. Main, and L. E. Green. 2012. The effects of early treatment for hindlimb lameness in dairy cows on four commercial UK farms. Vet. J. 193:626-632. http:// dx.doi.org/10.1016/j.tvjl.2012.06.043.

Ledgerwood, D. N., C. Winckler, and C. B. Tucker. 2010. Evaluation of data loggers, sampling intervals, and editing techniques for measuring the lying behavior of dairy cattle. J. Dairy Sci. 93:51295139. http://dx.doi.org/10.3168/jds.2009-2945.

Leonard, F. C., J. M. O. Connell, and O. Farrell. 1996. Effect of overcrowding on claw health in first-calved heifers. Br. Vet. J. 152:459472. http://dx.doi.org/10.1016/S0007-1935(96)80040-6.

Lim, P. Y., J. N. Huxley, J. A. Willshire, M. J. Green, A. R. Othman, and J. Kaler. 2015. Unravelling the temporal association between lameness and body condition score in dairy cattle using a multistate modelling approach. Prev. Vet. Med. 118:370-377. http:// dx.doi.org/10.1016/j.prevetmed.2014.12.015.

Lombard, J. E., C. B. Tucker, M. A. G. von Keyserlingk, C. A. Kopral, and D. M. Weary. 2010. Associations between cow hygiene, hock injuries, and free stall usage on US dairy farms. J. Dairy Sci. 93:4668-4676. http://dx.doi.org/10.3168/jds.2010-3225.

Mahendran, S., and N. Bell. 2015. Lameness in cattle 2. Managing claw health through appropriate trimming techniques. In Pract. 37:231-242. http://dx.doi.org/10.1136/inp.h2011.

Murray, R. D., D. Y. Downham, M. J. Clarkson, W. B. Faull, J. W. Hughes, F. J. Manson, J. B. Merritt, W. B. Russell, J. E. Sutherst, and W. R. Ward. 1996. Epidemiology of lameness in dairy cattle: Description and analysis of foot lesions. Vet. Rec. 138:586-591. http://dx.doi.org/10.1136/vr.138.24.586.

Nordlund, K., and N. B. Cook. 2003. A flowchart for evaluating dairy cow freestalls. Bov. Pract. 37:89-96.

Phillips, C. J., and I. D. Morris. 2000. The locomotion of dairy cows on concrete floors that are dry, wet, or covered with a slurry of excreta. J. Dairy Sci. 83:1767-1772. http://dx.doi.org/10.3168/jds. S0022-0302(00)75047-8.

Prescott, N. B., T. T. Mottram, and A. J. F. Webster. 1998. Relative motivations of dairy cows to be milked or fed in a Y-maze and an automatic milking system. Appl. Anim. Behav. Sci. 57:23-33. http://dx.doi.org/10.1016/S0168-1591(97)00112-3.

Refaai, W., M. Van Aert, A. M. Abd El-Aal, E. Behery, and G. Opsomer. 2013. Infectious diseases causing lameness in cattle with a main emphasis on digital dermatitis (Mortellaro disease). Livest. Sci. 156:53-63. http://dx.doi.org/10.1016/j.livsci.2013.06.004.

Sanders, A. H., J. K. Shearer, and A. De Vries. 2009. Seasonal incidence of lameness and risk factors associated with thin soles, white line disease, ulcers, and sole punctures in dairy cattle. J. Dairy Sci. 92:3165-3174. http://dx.doi.org/10.3168/jds.2008-1799.

Schüller, L. K., O. Burfeind, and W. Heuwieser. 2013. Short communication: Comparison of ambient temperature, relative humidity, and temperature-humidity index between on-farm measurements and official meteorological data. J. Dairy Sci. 96:7731-7738. http://dx.doi.org/10.3168/jds.2013-6736.

Schütz, K. E., A. R. Rogers, Y. A. Poulouin, N. R. Cox, and C. B. Tucker. 2010. The amount of shade influences the behavior and physiology of dairy cattle. J. Dairy Sci. 93:125-133. http://dx.doi. org/10.3168/jds.2009-2416.

Scott, V. E., K. L. Kerrisk, P. C. Thomson, N. A. Lyons, and S. C. Garcia. 2015. Voluntary cow traffic and behaviour in the premilking yard of a pasture-based automatic milking system with a feed supplementation regime. Livest. Sci. 171:52-63. http://dx.doi. org/10.1016/j.livsci.2014.11.002.

Solano, L., H. W. Barkema, E. A. Pajor, S. Mason, S. J. LeBlanc, J. C. Zaffino Heyerhoff, C. G. R. Nash, D. B. Haley, E. Vasseur, D. Pellerin, J. Rushen, A. M. de Passillé, and K. Orsel. 2015. Prevalence of lameness and associated risk factors in Canadian HolsteinFriesian cows housed in freestall barns. J. Dairy Sci. 98:6978-6991. http://dx.doi.org/10.3168/jds.2015-9652.

Somers, J. G. C. J., K. Frankena, E. N. Noordhuizen-Stassen, and J. H. M. Metz. 2003. Prevalence of claw disorders in Dutch dairy cows exposed to several floor systems. J. Dairy Sci. 86:2082-2093. http://dx.doi.org/10.3168/jds.S0022-0302(03)73797-7.

Somers, J. G. C. J., K. Frankena, E. N. Noordhuizen-Stassen, and J. H. M. Metz. 2005. Risk factors for digital dermatitis in dairy cows kept in cubicle houses in The Netherlands. Prev. Vet. Med. 71:11-21. http://dx.doi.org/10.1016/j.prevetmed.2005.05.002.

Sova, A. D., S. J. Leblanc, B. W. Mcbride, and T. J. Devries. 2013. Associations between herd level feeding management practices, feed sorting, and milk production in freestall dairy farms. J. Dairy Sci. 96:4759-4770. http://dx.doi.org/10.3168/jds.2013-6679.

Tremblay, M., J. P. Hess, B. M. Christenson, K. K. McIntyre, B. Smink, A. J. van der Kamp, L. G. de Jong, and D. Döpfer. 2016. Factors associated with increased milk production for automatic milking systems. J. Dairy Sci. 99:3824-3837. http://dx.doi. org/10.3168/jds.2015-10152.

von Keyserlingk, M. A. G., A. Barrientos, K. Ito, E. Galo, and D. M. Weary. 2012. Benchmarking cow comfort on North American freestall dairies: Lameness, leg injuries, lying time, facility design, and management for high-producing Holstein dairy cows. J. Dairy Sci. 95:7399-7408. http://dx.doi.org/10.3168/jds.2012-5807.

Westin, R., A. Vaughan, A. M. de Passillé, T. J. DeVries, E. A. Pajor, D. Pellerin, J. M. Siegford, E. Vasseur, and J. Rushen. 2016a. Lying times of lactating cows on dairy farms with automatic milking systems and the relation to lameness, leg lesions, and body condition score. J. Dairy Sci. 99:551-561. http://dx.doi.org/10.3168/ jds.2015-9737.

Westin, R., A. Vaughan, A. M. de Passillé, T. J. DeVries, E. A. Pajor, D. Pellerin, J. M. Siegford, A. Witaifi, E. Vasseur, and J. Rushen. 2016b. Cow and farm-level risk factors for lameness on dairy farms with automated milking systems. J. Dairy Sci. 99:3732-3743. http://dx.doi.org/10.3168/jds.2015-10414. 